\title{
PEMBERIAN BERAS ANALOG DAN SNACK IKAN BILIH SEBAGAI TERAPI GIZI PASIEN DENGAN SINDROM METABOLIK
}

\author{
Tiara Cornela Azqinar ${ }^{1}$ \\ ${ }^{1}$ Prodi Pendidikan Dokter, Fakultas Kedokteran, Universitas Lampung
}

\begin{abstract}
Supplementation of Analog Rice and Bilih Fish Snack as Nutritional Therapy for Metabolic Syndrome. Metabolic syndrome (SM) is a collection of symptoms consisting of obesity, insulin resistance, dyslipidemia, and hypertension. Poor consumption patterns can cause various diseases, one of which is metabolic syndrome. The purpose of this study was to determine the potential of analog rice with selective fish snacks as nutritional therapy for patients with metabolic syndrome. Thedatausedaresourcedfromvariousreferencesorliteraturethatarerelevant to the topic of the problem discussed. The type of data obtained is secondary and qualitative data. The result are condition of BC is characterized by an increase in increased blood sugarsothat a food source that has a low glycemic index is needed so that the body can digest longer. Analog rice is a processed product that can be made from some or all of the non-rice ingredients. The compound contained in analog rice is polyphenols. Polyphenols can in hibit the activity of digestive enzymes, especially trypsin and amylase so that it can reduce the digestibility of starch. In addition to the provision of analog rice, adequate nutrition is needed for metabolic syndrome patients using bilih fish snack (Mystacoleuseus padangensis Blkr) which has high nutritional content such as protein,calcium and zinc and is highly recommended for patients with metabolic syndrome. Conclusion is Provision of analog rice and bilih fish snack is highly recommended for patients with metabolic syndrome.
\end{abstract}

Keywords: Analog Rice, Bilih Fish, Metabolic Syndrome

\begin{abstract}
Abstrak: Pemberian Beras Analog dan Snack Ikan Bilih Sebagai Terapi Gizi Pasien Dengan Sindrom Metabolik. Sindroma metabolik (SM) adalah sekumpulan gejala yang terdiri dari obesitas, resistensi insulin, dislipidemia, dan hipertensi. Pola konsumsi yang kurang baik dapat menyebabkan berbagai macam penyakit salah satunya sindrom metabolik. Tujuan penelitian ini untuk mengetahui potensi beras analog dengan snack ikan bilih sebagai terapi gizi pasien dengan sindrom metabolik. Data-data yang dipergunakan bersumber dari berbagai referensi atau literature yang relevan dengan topic permasalahan yang dibahas. Jenis data yang diperoleh berupa data sekunder yang bersifat kualitatif maupun kuantitatif. Kondisi SM ditandai dengan peningkatan gula darah sehingga dibutuhkan sumber makanan yang memiliki indek glikemik rendah agar dapat dicerna lebih lama oleh tubuh. Beras analog merupakan produk olahan yang dapat dibuat dari sebagian atau seluruhnya bahan non-beras. Senyawa yang terkadung dalam beras analog adalah polifenol. Polifenol dapat menghambat aktivitas enzim pencernaan terutama tripsin dan amilase sehingga dapat menurunkan daya cerna pati. Selain pemberian beras analog, dibutuhkan nutrisi yang cukup untuk pasien sindrom metabolik dengan menggunakan snack ikan bilih(Mystacoleuseus padangensis Blkr) yang mana memiliki kandungan nutrisi seperti protein, kalsium dan zink yang tinggi dan sangat dianjurkan untuk diberikan pada penderita sindrom metabolik. Kesimpulannya adalah Pemberian beras analog dan snack ikan bilih sangat dianjurkan untuk diberikan pada penderita sindrom metabolik.
\end{abstract}


Kata Kunci: Beras Analog, Ikan Bilih, Sindrom Metabolik

\section{PENDAHULUAN}

Sindrom Metabolik(SM)merupakan sekumpulan gejala yang terdiri dari obesitas, resistensiinsulin, dislipidemia, dan hipertensi. Prevalensi SM dunia menurut Ford dkk(2002)menemukan bahwa pada respondenberusia26-82tahun terdapat $29,4 \%$ priadan $23,1 \%$ wanita menderita SM.

Sedangkan penelitian di Perancis menemukan prevalensi SM sebesar $23 \%$ padapriadan $21 \%$ pada wanita. Data dari Himpunan Studi Obesitas Indonesia (HISOBI) menunjukkan prevalensi SM sebesar 13,13\% (Alberti, Eckel dan Grundy, 2009).

Global Burden of Disease (GBD) menyebutkan bahwa terjadi peningkatan sindrom metabolic sebesar $82 \%$ diseluruh dunia selama rentang waktu 1990-2010. Menurut Ranasinghe dkk(2017)melalui tinjauan pustaka sistematisprevalensiSM berada dikisaran 11,9 hingga37,1\%di wilayah Asia-Pasifik yang terdiri dari Filipina, Cina, Sri Lanka, Taiwan, Singapura, Korea Selatan,Mongolia, dan Malaysia dengan prevalensi $11,9,21,3,24,3,25,5,26,9,31,3,32,8$ dan $37,1 \%$ (Ranasinghe dkk, 2017).

Tabel 1. Kriteria Sindrom Metabolik yang tidak memiliki sindrom tersebut. Saat ini, IDF merekomendasikan bahwa manajemen primer untuk sindrom metabolik adalah gaya hidup sehatseperti nutrisi yang baik dengan pembatasan kalori (untuk mencapai penurunan $5-10 \%$ berat badan pada tahun pertama) dan didukung oleh aktivitas fisik. Nutrisi yang baik untuk penderita DM masih terbatas namun saat ini sedang dikembangkan penggunaan beras analog dengan snack ikan bilih sebagai terapi nutrisi bagi penderita sindrom metabolic (Herningtyas dan $\mathrm{Ng}$, 2019; IDF,2018).

\section{METODE}

Data-data yang dipergunakan bersumber dari berbagai referensi atauliteratur yang relevan dengan topik permasalahan yang dibahas. Validitas dan relevansi referensi yang digunakan dapat dipertanggungjawabkan. Jenis data yang diperoleh berupa data sekunder yang bersifat kualitatif maupun kuantitatif. Penelitian ini menggunakan metode studi pustaka yang didasarkan atas hasil studi terhadap berbagai literatur yang telah teruji validitasnya, berhubungan satu sama lain, relevan dengan kajian tulisan serta mendukung uraian atau analisis pembahasan.

\begin{tabular}{|c|c|c|c|}
\hline Komponen & $\begin{array}{l}\text { Kriteria diagnosis WHO: } \\
\text { Resistensi insulin plus: }\end{array}$ & $\begin{array}{l}\text { Criteria diagnosis ATP III : } \\
\mathbf{3} \text { komponen di bawah ini }\end{array}$ & IDF \\
\hline $\begin{array}{l}\text { Obesitas } \\
\text { abdominal/ sentral }\end{array}$ & $\begin{array}{l}\text { Waist to hip ratio : } \\
\text { Laki-laki : }>0,9 \\
\text { Wanita }:>0,85 \text { atau } \\
\text { IMB }>30 \mathrm{Kg} / \mathrm{m}\end{array}$ & $\begin{array}{l}\text { Lingkar perut: } \\
\text { Laki-laki: } 102 \mathrm{~cm} \\
\text { Wanita : }>88 \mathrm{~cm}\end{array}$ & $\begin{array}{l}\text { Lingkar perut : } \\
\text { Laki-laki: } \geq 90 \mathrm{~cm} \\
\text { Wanita }: \geq 80 \mathrm{~cm}\end{array}$ \\
\hline $\begin{array}{l}\text { Hiper- } \\
\text { trigliseridemia }\end{array}$ & $\geq 150 \mathrm{mg} / \mathrm{dl}(\geq 1,7 \mathrm{mmol} / \mathrm{L})$ & $\geq 150 \mathrm{mg} / \mathrm{dl}(\geq 1,7 \mathrm{mmol} / \mathrm{L})$ & $\geq 150 \mathrm{mg} / \mathrm{dl}$ \\
\hline Hipertensi & $\begin{array}{l}\mathrm{TD} \geq 140 / 90 \mathrm{mmHg} \text { atau } \\
\text { riwayat terapi anti hipertensif }\end{array}$ & $\begin{array}{l}\mathrm{TD} \geq 130 / 85 \mathrm{mmHg} \text { atau } \\
\text { riwayat terapi anti hipertensif }\end{array}$ & $\begin{array}{l}\text { TD sistolik } \geq 130 \\
\mathrm{mmHg} \\
\mathrm{TD} \text { diastolik } \geq 85 \\
\mathrm{mmHg}\end{array}$ \\
\hline $\begin{array}{l}\text { Kadar glukosa } \\
\text { darah tinggi }\end{array}$ & $\begin{array}{l}\text { Toleransi glukosa terganggu, } \\
\text { glukosa puasa } \\
\text { terganggu,resistensi insulin } \\
\text { atau DM }\end{array}$ & $\geq 110 \mathrm{mg} / \mathrm{dl}$ & $\mathrm{GDP} \geq 100 \mathrm{mg} / \mathrm{dl}$ \\
\hline Mikro-albuminuri & $\begin{array}{l}\text { Rasio albumin urin dan } \\
\text { kreatinin } 30 \mathrm{mg} / \mathrm{g} \text { atau laju } \\
\text { eksresi albumin } 20 \mathrm{mcg} / \text { menit }\end{array}$ & & \\
\hline
\end{tabular}

Prevalensi SM di Indonesia menurut Herningtyas dan $\mathrm{Ng}$ (2019) adalah 21,66\% dengan prevalensi provinsi berkisar antara 0 hingga $50 \%$, sedangkan prevalensi etnis berkisar antara 0 hingga $45,45 \%$. Menurut International Diabetic Federation (IDF) bahwa 20-25 persen populasi di dunia menderita sindrom metabolikdanakanduakalilebihmungkin meninggal akibat serangan jantung atau stroke dibandingkan dengan orang-orang

\section{HASIL DAN PEMBAHASAN}

Sindroma metabolik adalah sekumpulan gejala yang terdiri dari obesitas, resistensi insulin, dislipidemia, dan hipertensi. Terdapat tiga definisi SM yaitu definisi World Health Organization (WHO), NCEP ATP-III dan International Diabetes Federation (IDF) yang tersaji pada Gambar 1.

Kriteria SM hingga saat ini masih menggunakan kriteria Gambar 1 dan belum 
ada kesepakatan kriteria sindroma metabolik secara international. Kejadian SM diduga berhubungan dengan pergeseran gaya hidup akibat pengaruh globalisasi. Gaya hidup masyarakat berubah menuju masyarakat modern dengan pola konsumsi makanan instan. Penelitian kohort yang dilakukan Lutsey dkk (2009) menjelaskan bahwa penelitian ini dilakukan selama sembilan tahun dengan melibatkan 9.514 subjek mendapatkanbahwaterdapatsekitar40\%

kasus baru sindrom metabolik dengan makanan barat, gorengan dan konsumsi daging dapat meningkatkan sindrom metabolik. Penelitian lain menyebutkan konsumsi produk berbahan dasar susu rendahlemak,ikan, danserealyangtinggi melindungi terjadinya sindrom metabolik (WHO, 2014; Lutsey, Steffen dan Steven, 2009).

Riset Kesehatan Dasar (Riskesdas) tahun 2013 adalah kecenderungan proporsi penduduk usia $>10$ tahun yang kurang mengonsumsi sayur dan buah sebanyak93,5\%.Konsumsimakananatau

minuman manis $\geq 1$ kali dalam sehari secara nasional adalah $53,1 \%$, sedangkan konsumsi makanan berlemak, berkolesterol dan makanan gorengan $\geq 1$ kali per hari sebesar $40,7 \%$ dan penduduk Indonesia mengonsumsi penyedap $\geq 1$ kali dalam sehari sebesar 77,3\%. Penelitian Mozaffarian dkk (2012) menyebutkan bahwa pola konsumsi tersebut yang cenderung rendah serat namun tinggi lemak, kolesterol, gula dan natrium, kurangnya aktivitas merupakan faktor risiko terjadinya obesitas dan sindrom metabolik (Kemenkes, 2013; Mozaffarian dkk,2012).

Pola konsumsi yang kurang baik dapat menyebabkan berbagai macam penyakit salah satunya sindrom metabolik. Kondisi SM ditandai dengan peningkatan peningkatan gula darah sehingga dibutuhkan sumber makanan yang memiliki indek glikemik rendah agar dapat dicerna lebih lama oleh tubuh. Indeks glikemik (IG) merupakan klasifikasi pangan berdasarkan dalammenaikkankadarguladarah.Halini

digunakan sebagai acuan dalam menentukan jumlah dan jenis pangan sumber karbohidrat yang tepat untuk meningkatkan maupun menjaga kesehatan. Pangan yang menaikkan kadar gula darah dengan cepat memiliki IG tinggi,sebaliknyapanganyangmenaikkan kadar gula darah dengan lambat memiliki
IG rendah. Pangan IG rendah diperlukan untuk mengendalikan rasa lapar, nafsu makan, dan kadar gula darah. Selain itu pangan IG rendah dapat membantu menurunkan berat badan. Pangan IG rendah sangat baik dikonsumsi oleh penderita sindrom metabolic (Mirshra, Mirsha dan Rao,2012).

Beras analog merupakan produk olahan yang dapat dibuat dari sebagian atau seluruhnya bahan non-beras. Selain itu, Budijanto dan Yuliyanti (2012) mengatakan beras analog yangberbentuk seperti butiran beras dapat dibuat dari tepung non-beras. Penelitian oleh Zhuang dkk (2010) menggunakan beras patah (menir) sebagai bahan bakupembuatan beras analog dengan teknologi ekstrusi. ${ }^{22}$ Beberapa bahan baku non-beras yang telah dimanfaatkan dalam pembuatan beras analog adalah sorgum, jagung kuning, bekatul, dan kedelai, singkong dan ampas kelapa, jagung, sorgum dan sagu aren, serta jagung putih (Budijanto dan Yuliyanti, 2012; Zhuang dkk,2010).

Pembuatan beras analog dilakukan dengan dua metode yaitu granulasi dan ekstrusi. Perbedaannya adalah pada tahapan gelatinisasi adonan dan tahapan pencetakan. Hasil cetakan metode granulasi adalah butiran sedangkan pada metode ekstrusi adalah bulat lonjong. Pada penelitian ini digunakan teknologi ekstrusi pada proses pembuatan beras analog. Ekstrusi merupakan proses pengolahan pangan yang mengkombinasikan beberapa unit operasi berkesinambungan. Proses ekstrusi meliputi proses pencampuran, pemasakan, pengadonan, shearing, pembentukan, dan pemotongan (Kurniawati,2013).

Pemanfaatan beras analog melalui jagung dan sorgum sudah digunakan karena jagung mengandung serat pangan tinggi dan indeks glikemik rendah. Sedangkan, sorgum memiliki kadar protein dan serat pangan yang tinggiyaitu berturut-turut $11,61 \%$ dan $4,09 \%$. Penelitian yang dilakukan oleh Andri (2013) menjelaskan bahwa beras analog yang berbasis tepung sorgum dan jagung kuning memiliki nilai indeks glikemik (IG) 47,09 dengan kadar fenol 0,10 mg dan serat pangan $5,22 \%$. Oleh karena itu, beras analog dari komposisi jagung dan sorgum berpotensi menjadi pangan fungsional dan memiliki indeks glikemik rendah. Selain itu, penggunaan kedelai yang mengandung protein lebih dari 35\% dan nilai indeks glikemik yang rendah yaitu 
21 sedang dikembangkan karena kedelai merupakan sumber serat pangan dan memiliki antioksidan seperti polifenol yang dapat dijadikan sebagai makanan fungsional. Selain itu, beras analog juga dapat memiliki nilai IG yang rendah,yaitu54 dengan kandungan serat 13,3\% dan kapasitas antioksidan 7,51 $\mu \mathrm{g}$ CEQ/ mg sampel (Andri, 2013; Kharisma, 2013).

Senyawa yang terkadung dalam beras analog adalah polifenol. Polifenol dapat menghambat aktivitas enzim pencernaan terutama tripsin dan amilase sehingga dapat menurunkan daya cerna pati. Enzim a-amilase terlibat dalam pemecahan pati menjadi disakarida dan oligosakarida, selanjutnya enzim aglukosidase dalam usus mengkatalisis pemecahan disakarida untuk membebaskan glukosa yang kemudian diserap dalam sirkulasi darah. Penghambatan enzim ini akan memperlambat pemecahan pati di saluran gastro-intestinal, sehingga mengurangi hiperglikemia-postprandial. Penelitian terdahulu tentang polifenol menduga bahwa aktivitas antioksidan fenol dapat memengaruhi lima jembatan disulfida yang terletak di permukaan luar amilase dan menginduksi penghambatan dengan mengubah modulasi dalam struktur enzim. Penghambatan enzim oleh ekstrak fenol akan mengakibatkan penghancuran secara lambat disakarida untuk menghasilkan glukosa, sehingga mengurangi penyerapan glukosa pada usus kecil. Selain itu, terdapat beberapa faktor yang dapat mempengaruhi nilai IG pangan antara lain perbandingan amilosa dan amilopektin, komponen monosakarida, kadar serat, cara pengolahan, pangan, ukuran partikel, kematangan dan interaksi terhadap pati (Noviasari, 2013).

Selain pemberian beras analog, dibutuhkan nutrisi yang cukup untuk pasien sindrom metabolic dengan menggunakan snack ikan bilih. Ikan bilih (Mystacoleuseus padangensis Blkr) merupakan makanan lokal dari Sumatera Baratyangmengandungsengdankalsium tinggi. Sebuah studi pendahuluan menggunakan metode pengeringan menunjukkan bahwa tepung ikan bilih mengandung 14,56-23,38 mg seng dan $3495,00-4786,53 \mathrm{mg}$ kalsium per $100 \mathrm{~g}$. Kandungan seng dan kalsium terendah diperoleh dari metode pengeringan matahari langsung dan paling tinggi dengan pengeringan oven. Karena ituikan
Bilih dapat dijadikan alternatif untuk sumber seng dan kalsium dengansindrom metabolik.

Kandungan energi pada ikan bilih adalah $5,83 \%$ energi per porsi $( \pm 30 \mathrm{~g}$ ) atau29,14\%per100gdandalamkategori kebutuhan energi $2.150 \mathrm{kkal}$ dapat memenuhi $15,25 \%$ dari $100 \mathrm{~g}$. Selain itu, ikan bilih memiliki kandungan protein yang cukup tinggi sehingga dapatmenjadi sumber protein alternatif, terutama pada anak-anak, remaja dan pasien dengan sindrom metabolik yang membutuhkan protein tinggi untukmendukung pertumbuhan mereka. Berdasarkan referensi label nutrisi setiap porsi bilah ikan $( \pm 30 \mathrm{~g})$ sama dengan $13,3117,50 \%$ atau $66,54-87,50 \%$ per $100 \mathrm{~g}$ kebutuhan protein (Noviasari, 2013).

Protein digunakan sebagai sumber glukosa darah dalam kondisi hipoglikemia untuk mencegah hipoglikemia. Konsumsi makanan berprotein tinggi pada sindrom metabolik dianjurkan untuk mengurangi lonjakan kadar glukosa darah. Protein adalah modulator penting dari homeostasis glukosa dengan mempromosikan resistensi insulin dan meningkatkan glukoneogenesis, meskipun dietproteintinggitelahmenunjukkanefek menguntungkan pada homeostasis glukosa dalam uji coba jangka pendek. Jumlah asupan protein ini dapat bermanfaat dengan meningkatkan kontrol glikemik, menjaga massa tubuh tanpa lemak selama penurunan berat badan pada sindrom metabolic (Yousif A, Nhepera D, Johnson S,2012).

Selain itu, ikan bilih juga mengandung zink sebanyak 3,29-4,58mg/ $100 \mathrm{~g})$ dan kandungan ini cukup tinggi, daripadadagingsapi $(4,1 \mathrm{mg})$, ikangabus $(0,4$ $\mathrm{mg})$, tuna $(1,6 \mathrm{mg})$, telur ayam $(1,5 \mathrm{mg})$, telur bebek $(1,8 \mathrm{mg})$, dan daging ayam $(1,8 \mathrm{mg})$ dalamper $100 \mathrm{~g}$.Penelitian

menunjukkanbahwadefisiensizinksecara signifikan terkait dengan pengerdilan dan mempengaruhi banyak sistem organ termasuk sistem saraf pusat, imun, skeletal. Seng juga merupakan stimulator pertumbuhan jaringan tulang yang kuat yangmerangsangmetabolismetulangdan sintesis protein tulang. Kandungan seng tulang terbukti menurun dalam penuaan, pembongkaran kerangka, kondisi pascamenopause dan penyakit degeneratif lainnya menunjukkan perannya dalam gangguan tulang. Sun dkk (2009) menjelaskan bahwa asupan seng yang lebih tinggi terkait akan menurunkan risiko 
diabetes meliitus (DM).Zink (Zn) memegang peranan esensial dalam semua sel, perkembangan fungsi reproduksi pria dan spermatogenesis, terutama perubahan testosteron menjadi dehidrotestosteron yang aktif. Zink berperan penting dalam memelihara sistem imun. Sebagai katalisator, enzim superoksida dismutase (SOD) membutuhkan tembaga (Cu) dan Znyangberadadidalamsitosolsemuasel terutama eritrosit. Enzim tersebut diduga memusnahkan anion superoksidayang merusak, yang dapat memicu terbentuknya plak pada proses aterosklerosis (Gullarte MA, Gomez M, Rossel CM, 2015; Sun dkk,2009).

Kandungan nutrisi yang tinggi pada ikan bilih adalah kalsium. Kandungan kalsium batang ikan dalam penelitian ini berkisar antara 597,61 hingga 922,23mg. Kalsium merupakan nutrisi pembentukan dan metabolisme tulang. Konsumsi kalsiumyangrendahberhubungandengan osteoporosis. Kalsium penting tidakhanya kerangka, tetapi juga konkurensi otot, regulasi detak jantung, transmisi impuls saraf, regulasi tekanan darah dan fungsi kekebalan tubuh serta proses fisiologis penting lainnya. Kalsium juga mengambil peran yang semakin penting dalam pemeliharaan integritas skeletasl pada wanita menopause. Suplementasi kalsium dalam kehamilan berpotensi mengurangi hasil buruk kehamilan terutama dengan mengurangi risiko mengembangkan gangguan hipertensi, yang terkait dengan sejumlah besar kematian ibu dan kelahiran bayi prematur. Selain itu, penelitian Mitri dkk (2011) menemukan bahwa konsumsi kalsium 600-1.000 mg per hari memiliki efek menguntungkan pada diabetes. Konsumsi makanan yang kaya kalsium juga dikaitkan dengan penurunan risiko kejadian T2DM, di mana asupan> 1.200 mg per hari mengurangi risiko T2DM sebesar 33\% dibandingkan dengan $<400$ IU (Mitri dkk, 2011).

Studi cross sectional menunjukkan rendahnya asupan kalsium berhubungan dengan kejadian sindrom metabolik di mana salah satu tanda dari sindrom metabolik adalah diabetes melitus. Suatu studi menunjukkan wanita yang tinggal didareah tropis mengalami ketidakcukupan asupan kalsium. Hal ini didukung penelitian yang dilakukan di Jerman, bahwa wanita usia 45-64 tahun memiliki status kalsium yang lebih rendah dibandingkan usia lebih dari 18-44 tahun. Insufisiensi kalsium selain disebabkan karena kurangnya paparan sinar matahari juga disebabkan kurangnya asupan kalsium dari luar tubuh. Beberapa studi menunjukkan terdapat hubungan yang signifikan antara status kalsium dengan asupan klasium yang mana asupan klasium berhubungan signifikan dengan kadar glukosa darah puasa dan lingkar pinggang (Mitri dkk,2011).

Snack Ikan bilih diproduksi dengan cara dibersihkan dari kotoran dan dicuci bersih, ikan bilih (seluruh tubuh dan kepala) kemudian dikukus selama 45 menit dan dikeringkan dalam oven pada suhu 100 ○ C selama 5 jam. Ikan Bilih kering dihaluskan dengan blender kering, kemudian diayak dan dijadikan snack. Snack ikan bilih dapat dimanfaatkan sebagai sumber nutrisi protein, seng dan kalsium untuk penderita DM khususnya sindrom metabolic (Nandhani dan Yunianta, 2015).

\section{KESIMPULAN}

Pemberian beras analog dengan snack ikan bilih dapat dimanfaatkan sebagai sumber nutrisi karbohidrat dengan indeks glikemik rendah, protein, seng dan kalsium untuk penderita DM khususnya sindrom metabolik.

\section{DAFTAR PUSTAKA}

Alberti KGMM, Eckel RH, Grundy SM, AA, Hinda, Ki dkk. (2009). Harmonizing the metabolicsyndrome: a joint interim statement of the international diabetes federation task

forceonepidemiologyandpreventio $\mathrm{n}$; National Heart, Lung, and Blood Institute; American HeartAssociation; world heart federation; international. Circulation.120(16):1640-5.

Andri YI. (2013). Indeks glikemik dan karakterisasi kimia beras analog berbahan dasar jagung, sorgum dan sagu aren [skripsi]. Bogor: Institut PertanianBogor.

Budijanto S, Yuliyanti. (2012). Studi persiapan tepung sorgum (Sorghum bicolor L.Moench) dan aplikasinya pada pembuatan beras analog. $J$ Tek Pert.13(3):177-186.

Gullarte MA, Gomez M, Rossel CM. (2013). Impact of legume flours on quality and in vitro digestibility of starch and protein from gluten- 
free cakes. J Food Bioprocess Tech. 142- 3150.

Herningtyas dan Ng. (2019). Prevalence and distribution of metabolic syndrome and its components among provinces and ethnicgroupsinIndonesia.BMCPu blic Health.19(377):1-12.

IDF. (2018). The IDF Concencus Worldwide Definition of the Metabolic Syndrome. Journal American Medical Association. 213(12):1345-52.

Kementerian Kesehatan Republik Indonesia. (2013). Riset kesehatan dasar (Basic Health Research). Jakarta: Kementerian Kesehatan RepublikIndonesia.

Kharisma T. (2013). Formulasi beras analog putih berbasis pati sagu (Metroxylon sagu R.), singkong (Manihot esculenta Crantz), dan ampas kelapa (Cocos nucifera L.) [skripsi]. Bogor: Institut Pertanian Bogor.

Kurniawati M. (2013). Stabilisasi bekatul dan penerapannya padaberas analog [tesis]. Bogor: Institut Pertanian Bogor.

Lutsey PL, Steffen LM, Stevens J. (2009). Dietary intake and the development of the metabolic syndrome: The atherosclerosis risk in communities study. Circulation. 117(6):754-61.

Mishra A, Mishra HN, Rao PS. (2012). Preparation of rice analogues using extrusion technology. Int $J$ Food Sci Tech.47:1789-1797.

Mitri J, Hughes BD, Hu Fb, Pittas AG. (2011). Effects of vitamin D and calcium supplementation on pancreatic $\beta$ cell function, insulin sensitivity and glycemia in adults at high-risk on diabetes: The calcium and vitamin $D$ for diabetes mellitus (CaDDM) randomized controlled trial. Am J Clin Nutr.94(2):486-894

Mozaffarian D, Afshin A, Benowitz NL, Bittner V, Daniels SR, Franch HA, dkk. (2012). Population approaches to improve diet, physical activity, and smoking habits: A scientificstatement from the American Heart Association. Circulation. 126(12):1514-63.

Nandhani SD, Yunianta. (2015). Pengaruh tepung labu kuning, tepung lele dumbo, natrium bikarbonat terhadap sifat fisiko, kimia organoleptic cookies. J Pangan \& Agroind. 3(3):918-927.

Noviasari S, Kusnandar F, BudijantoS. (2013). Pengembangan beras analog dengan memanfaatkan jagung putih. J Teknol Industri Pangan. 24:195- 201.

Ranasinghe $P$, Mathangasinghe $Y$, Jayawardena R, Hills AP, Misra A (2017). Prevalence and trends of metabolic syndrome among adults in the asiapacific region: asystematicreview. BMC Public Health. 17(101):1- 12.

Rini. (2015). Sindrom Metabolik. JUKE Unila. 2015;4(4):88-93.

World Health Organization. (2014). Obesity: Preventing and Managingthe Global Epidemic. Geneva:WHO.

Yousif A, Nhepera D, Johnson S. (2012). Influence of sorghum flour addition on flat bread in vitro starch digestibility, antioxidant capacity and consumer acceptability. J Food Chem. 134:880-887.

Zhuang $\mathrm{H}$, An $\mathrm{H}$, Chen $\mathrm{H}$, Xie $\mathrm{Z}$, Zhao J, Xu X, Jin Z. (2010). Effect of Extrusion Parameters on Physicochemical Properties of Hybrid Indica Rice (Type 9718) Extrudates. $J$ of Food Processing and Preserv. 34:10801102. 